Supporting Information for:

\title{
Vanadium Pyridonate Catalysts: Isolation of Intermediates in the Reductive Coupling of Alcohols
}

Samuel E. Griffin and Laurel L. Schafer*

Department of Chemistry, University of British Columbia, 2036 Main Mall, Vancouver, British

Columbia, Canada V6T 1Z1

\section{Table of Contents}

General Considerations

Synthesis of Complexes

NMR Tube Experiments

Alcohol Substrate Table 


\section{General Considerations}

All air and moisture sensitive compounds were manipulated under inert $\mathrm{N}_{2}$ atmosphere using an MBraun LABmaster glovebox or standard Schlenk techniques. Glassware was allowed to dry in a $160{ }^{\circ} \mathrm{C}$ oven prior to transferring to the glovebox or Schlenk manifold. Toluene and hexanes were passed through an activated alumina column under $\mathrm{N}_{2}$ gas, collected in a Teflon sealed Straus flask, and sparged with $\mathrm{N}_{2}$ for 30 minutes prior to use. THF, benzene- $d_{6}$, and toluene- $d_{8}$ were dried over sodium metal and distilled under $\mathrm{N}_{2}$ and collected in a Teflon sealed Straus flask prior to use. Diatomaceous earth was dried in an oven at $160{ }^{\circ} \mathrm{C}$ for at least 24 hours before transferring to the glovebox. J. Young NMR tubes $(8$ " x $5 \mathrm{~mm})$ with Teflon screw-caps were used for NMR reactions. ${ }^{1} \mathrm{H}$ NMR spectra were collected using a Bruker $300 \mathrm{MHz}$ or 400 MHz Avance spectrometer at $298 \mathrm{~K}$ unless otherwise noted. Chemical shifts, $\delta$, are reported relative to the corresponding residual protio solvent in parts per million $(\mathrm{ppm})$. For NMR yield determinations, $\mathrm{T}_{1}$ relaxation times for the relevant signals were estimated using a spin-echo pulse sequence and relaxation delays were extended accordingly during ${ }^{1} \mathrm{H}$ NMR data collection. Effective magnetic moments were determined using Evans Method, ${ }^{1-3}$ using coaxial inserts containing 1 mol\% cyclooctane in benzene- $d_{6}$. Mass spectra (MS) were collected using a Jeol AccuTOF GCv 4G spectrometer equipped with a Liquid Injection Field Desorption Ionization (LIFDI) probe, and fragments are given in mass per charge number $(\mathrm{m} / \mathrm{z})$. GC-MS experiments were performed using an Agilent 7890A GC equipped with a 5975C inert XL $\mathrm{EI} / \mathrm{CI}$ mass detector, operated in positive $\mathrm{CI}$ mode and using methane as the reagent gas. Elemental analysis (EA) was performed with a Thermo Flash 2000 Elemental Analyzer. The elemental composition values are given in percentages (\%). Single crystal X-ray diffraction data were collected using a Bruker X8 APEX or Bruker APEX DUO diffractometer. All chemicals were purchased from commercial sources and used without further purification, and those which were not already dried and stored under inert atmosphere were either dried over calcium hydride and degassed via the freeze-pump-thaw method or sublimed or dried under high vacuum before use. Trimesitylvanadium(III)-tetrahydrofuran was prepared according to a literature method. ${ }^{4}$ 


\section{Synthesis of Complexes}

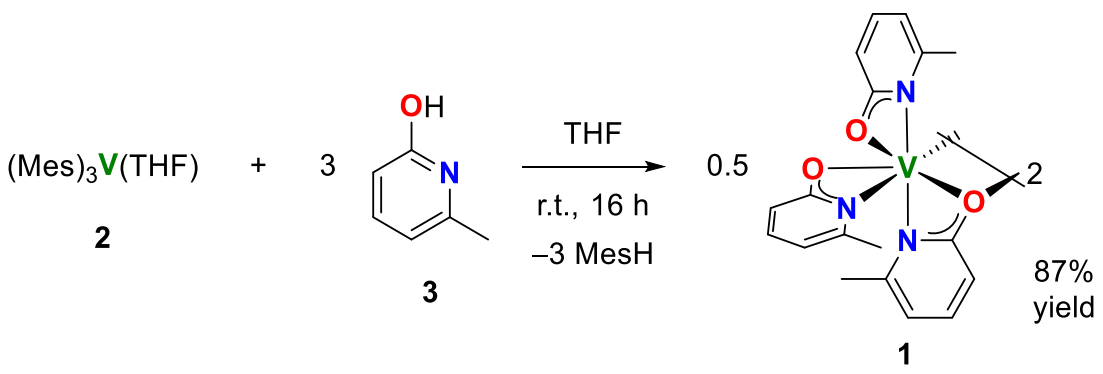

Synthesis of 1: A $20 \mathrm{~mL}$ vial was charged with tris(mesityl) complex 2 (0.100 g, $0.214 \mathrm{mmol})$ before transferring pyridone $3(0.070 \mathrm{~g}, 0.64 \mathrm{mmol})$ to the same vial with $\sim 5 \mathrm{~mL}$ THF, producing a clear, dark amber-pink solution. The solution was then stirred at room temperature. After $16 \mathrm{~h}$, the volatiles were removed in vacuo to give an amorphous pink residue. To this residue, $\sim 3 \mathrm{~mL}$ hexanes were added and the suspension was triturated to induce precipitation of a pink powder before removal of the volatiles in vacuo; this trituration/removal of volatiles procedure was repeated once more. Finally, the sample was put under high vacuum for $14 \mathrm{~h}$ to remove residual mesitylene and give $0.070 \mathrm{~g}$ of $\mathbf{1}$ as a pink powder ( $87 \%$ yield). Recrystallization from a saturated THF solution at room temperature for $24 \mathrm{~h}$ gave pink crystals suitable for X-ray diffraction. Effective magnetic moment (Evans' method, $400 \mathrm{MHz}, \mathrm{C}_{6} \mathrm{D}_{6}, 25^{\circ} \mathrm{C}$ ): $\mu_{\mathrm{eff}}=2.89 \mu_{\mathrm{B}}$; ${ }^{1} \mathrm{H}$ NMR $\left(\mathrm{C}_{7} \mathrm{D}_{8}, 300 \mathrm{MHz}\right) \delta=24.74,13.40,0.11,-17.82$. The molecular ions of the dimeric complex and the corresponding monomeric complex were observed: MS(LIFDI) $\mathrm{m} / \mathrm{z} 750[\mathrm{M}]^{+}, \mathrm{m} / \mathrm{z} 375[\mathrm{M}-$ $\left.\mathrm{V}\left(\mathrm{C}_{6} \mathrm{H}_{6} \mathrm{NO}\right)_{3}\right]^{+}$; Anal Calcd for $\mathrm{C}_{36} \mathrm{H}_{36} \mathrm{~N}_{6} \mathrm{O}_{6} \mathrm{~V}_{2}: \mathrm{N}, 11.20 ; \mathrm{C}, 57.61 ; \mathrm{H}, 4.83$. Found: N, 11.03; C, 57.64; H, 4.86 .
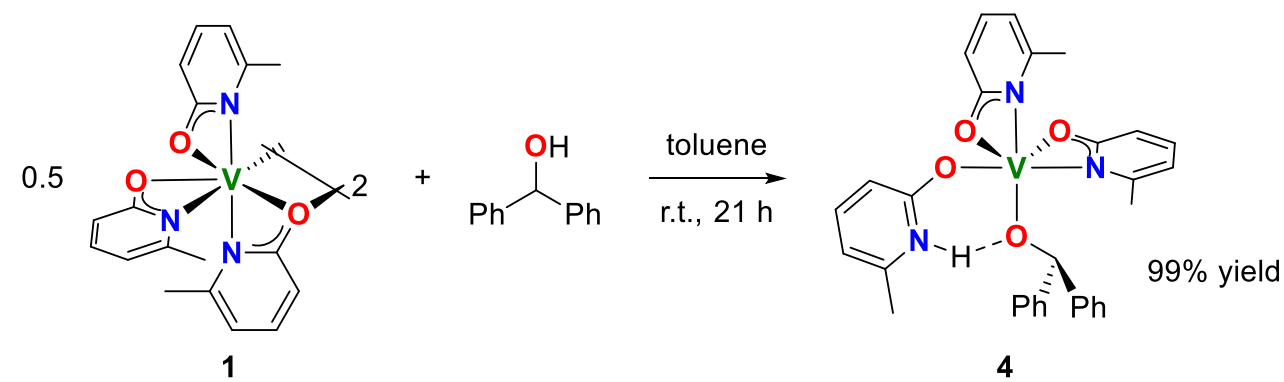

Synthesis of 4: A $20 \mathrm{~mL}$ vial was charged with tris(pyridonate) dimer 1 (0.066 g, $0.088 \mathrm{mmol})$ before adding $\sim 2 \mathrm{~mL}$ toluene to give a pale-yellow suspension of the pink solid. Benzhydrol $(0.032 \mathrm{~g}, 0.18 \mathrm{mmol})$ was then transferred the suspension using $\sim 2 \mathrm{~mL}$ toluene, immediately producing a clear, moss green solution. After stirring at room temperature for $21 \mathrm{~h}$, the solution was filtered through diatomaceous earth and $\sim 3 \mathrm{~mL}$ hexanes were added. The solution was then concentrated in vacuo to $\sim 1 \mathrm{~mL}$ of solvent, and $\sim 3$ 
$\mathrm{mL}$ hexanes were added once again, causing a small amount of green solid to precipitate out. This concentration/hexanes addition procedure was repeated two more times before completely removing the volatiles in vacuo to give $0.098 \mathrm{~g}$ of $\mathbf{4}$ as a light green powder (99\% yield). Dissolving the solid in $\sim 2 \mathrm{~mL}$ hot toluene and letting the solution cool to room temperature for $24 \mathrm{~h}$ gave dark green crystals suitable for X-ray diffraction. Effective magnetic moment (Evans' method, $400 \mathrm{MHz}, \mathrm{C}_{6} \mathrm{D}_{6}, 25^{\circ} \mathrm{C}$ ): $\mu_{\text {eff }}=2.62 \mu_{\mathrm{B}} ;{ }^{1} \mathrm{H}$ NMR $\left(\mathrm{C}_{7} \mathrm{D}_{8}, 300 \mathrm{MHz}\right) \delta=30.19,26.90,15.59,11.51,-3.49,-5.23,-22.76,-24.44$; The molecular ion was observed, however higher masses were also observed including that of dimer 3: MS(LIFDI) $\mathrm{m} / z, 559$ $[\mathrm{M}]^{+}$; Anal Calcd for $\mathrm{C}_{31} \mathrm{H}_{30} \mathrm{~N}_{3} \mathrm{O}_{4} \mathrm{~V}: \mathrm{N}, 7.51 ; \mathrm{C}, 66.54 ; \mathrm{H}, 5.40$. Found: N, 7.44; C, 66.79; H, 5.40.

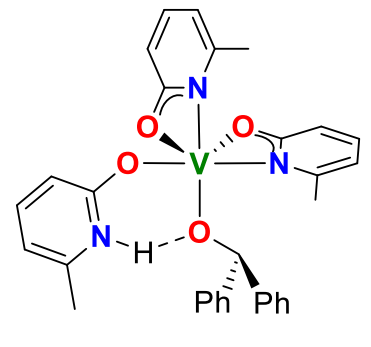

4

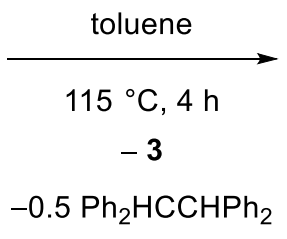

$-0.5 \mathrm{Ph}_{2} \mathrm{HCCHPh}_{2}$

Synthesis of 5: A $2 \mathrm{~mL}$ bomb was charged with alkoxide complex 4 (0.030 g, $0.054 \mathrm{mmol})$ and a stir bar before adding $\sim 1.5 \mathrm{~mL}$ toluene and gently heating to give a dark green solution. The bomb was then sealed, placed in an oil bath set to $115{ }^{\circ} \mathrm{C}$, and stirred for 4 hours. During this time the solution turned to dark turquoise. The solution was then filtered through diatomaceous earth and the volatiles were removed in vacuo to give a mixture of colourless and seafoam green solids. The mixture was then dissolved in a minimum amount of hot toluene $(\sim 0.5 \mathrm{~mL})$ and left to stand at room temperature. After 48 hours, a mixture of colourless and sky-blue crystals formed, both of which were suitable for X-ray diffraction. The colourless and blue crystals corresponded to 1,1,2,2-tetraphenylethane and complex 5, respectively. Repeated attempts to separate these two products were unsuccessful, thus a yield for complex $\mathbf{5}$ could not be obtained. ${ }^{1} \mathrm{H}$ $\mathrm{NMR}\left(\mathrm{C}_{7} \mathrm{D}_{8}, 300 \mathrm{MHz}\right) \delta=13.91$. The molecular ions of the dimeric complex and the corresponding monomeric complex were observed: MS(LIFDI) $m / z 566[\mathrm{M}]^{+}, m / z 283\left[\mathrm{M}-\mathrm{VO}\left(\mathrm{C}_{6} \mathrm{H}_{6} \mathrm{NO}\right)_{2}\right]^{+}$. Satisfactory elemental analysis could not be obtained due to persistent co-crystallization of organic product. 


\section{NMR Tube Experiments}
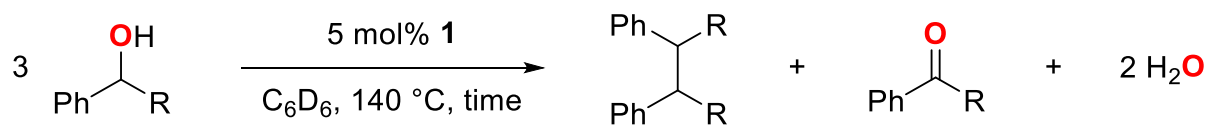

General Procedure for Catalytic Reductive Coupling of Alcohols: To separate small vials, catalyst 1 $(0.0013 \mathrm{mmol})$, alcohol substrate $(0.026 \mathrm{mmol})$, and 1,3,5-trimethoxybenzene $(0.0083 \mathrm{mmol})$ were all weighed. Using $800 \mu \mathrm{L} \mathrm{C}_{6} \mathrm{D}_{6}$, the contents of the vials were mixed thoroughly to produce a light green solution. The solution was then transferred to a J. Young tube and placed in an oil bath set to $140{ }^{\circ} \mathrm{C}$ for 24 or 48 hours (CAUTION: As $140{ }^{\circ} \mathrm{C}$ is well above the boiling point of $\mathrm{C}_{6} \mathrm{D}_{6}$, a blast shield should be used in case the J. Young tube bursts. Though these tubes are designed to withstand pressure, the blast shield should still be used as a precaution). The yields were determined based on the average of two runs, using the relative integrations of the benzylic protons in the product and ortho protons in the aryl ketone byproduct compared to those of the methyl protons in the 1,3,5-trimethoxybenzene internal standard. The solutions were then quenched with methanol, filtered through diatomaceous earth, and diluted in methanol prior to GC-MS analysis to confirm formation of all products.

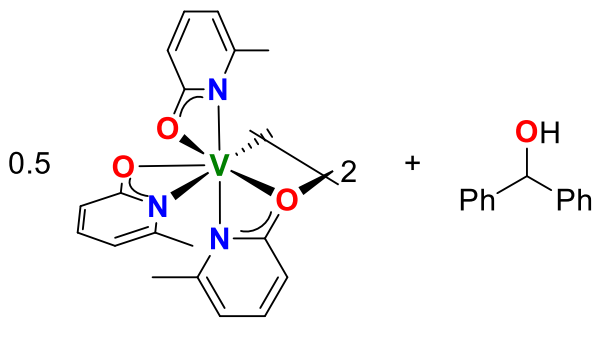

1
1) toluene- $d_{8}$

r.t., $50 \mathrm{~min}$

2) $100{ }^{\circ} \mathrm{C}, 70 \mathrm{~h}$

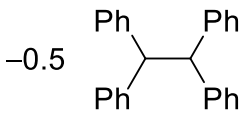

(N)
0.5

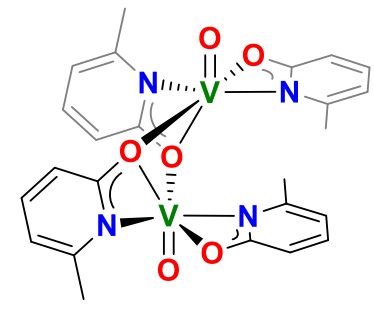

5

Generation of 5 in situ: To separate small vials, complex 1 (0.002 g, $0.003 \mathrm{mmol})$ and benzhydrol (0.001

$\mathrm{g}, 0.005 \mathrm{mmol}$ ) were weighed. The alcohol was transferred quantitively to the complex using toluene- $d_{8}$ to give a peach coloured solution, which was transferred to a J. Young tube. The total volume of toluene- $d_{8}$ used was $\sim 1.5 \mathrm{~mL}$. After 50 minutes at room temperature, during which time the ${ }^{1} \mathrm{H}$ NMR spectrum was obtained, the tube was placed in an oil bath set to $100{ }^{\circ} \mathrm{C}$ for 70 hours. The ${ }^{1} \mathrm{H}$ NMR spectrum was obtained once more after the heating was finished.
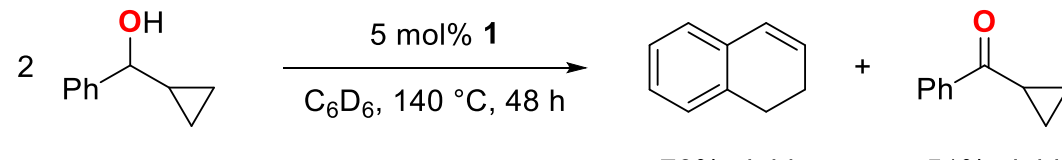

$51 \%$ yield 
Catalysis with $\boldsymbol{\alpha}$-Cyclopropylbenzyl Alcohol: This reaction was carried out in the same way as the catalytic reductive coupling of 1-phenylethanol except that $\alpha$-cyclopropylbenzyl alcohol (0.026 mmol) was used as the substrate. The ${ }^{1} \mathrm{H}$ NMR spectrum after the reaction showed the formation of 1,2dihydronapthalene in $70 \%$ yield, which results from the ring-opening reaction of a benzylic radical with the cyclopropyl substituent; ${ }^{5}$ thus, this is indicative of a radical process.
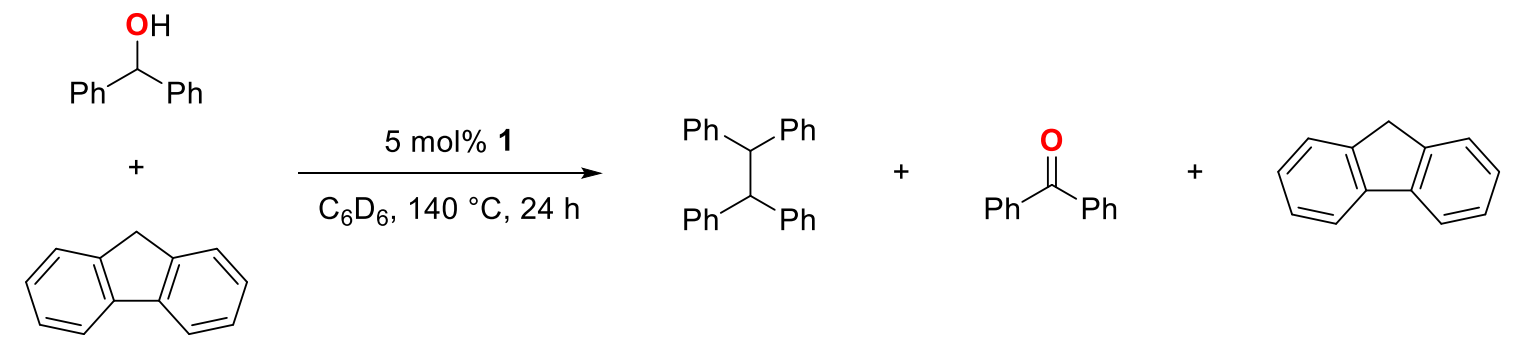

Radical Trap Test with Fluorene: This reaction was carried out in the same way as the catalytic reductive coupling of benzhydrol except that one equivalent of fluorene $(0.026 \mathrm{mmol})$ was included in the reaction mixture. The ${ }^{1} \mathrm{H}$ NMR spectrum after the reaction showed no difference to that of the catalytic reductive coupling of benzhydrol other than the presence of completely unreacted fluorene.
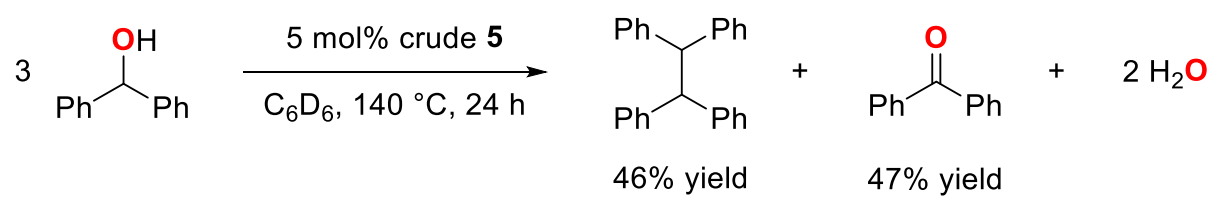

Catalysis using Crude 5: This reaction was carried out in the same way as the catalytic reductive coupling of benzhydrol except that a crude sample of dimer 5, containing 1,1,2,2-tetraphenylethane impurity, was used as the catalyst $(0.0013 \mathrm{mmol})$. The moles of product already present at $\mathrm{t}=0$ were subtracted from the total after the reaction when calculating the yield.

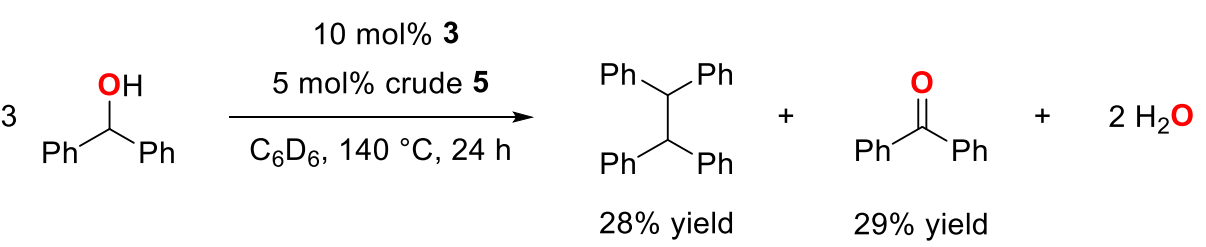

Catalysis using Crude 5 with Added Pyridone: This reaction was carried out in the same way as the catalytic reductive coupling of benzhydrol using crude 5 above, except with 10 mol\% of pyridone 3 added to the reaction. The moles of product already present at $\mathrm{t}=0$ were subtracted from the total after the reaction when calculating the yield. 


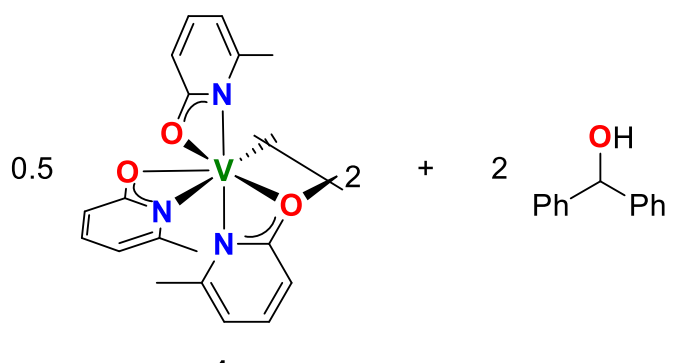

1
1) toluene- $d_{8}$

r.t., $75 \mathrm{~min}$

2) $140{ }^{\circ} \mathrm{C}, 22 \mathrm{~h}$

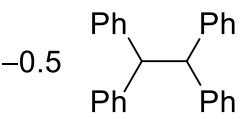

$\underbrace{\mathrm{O}_{\mathrm{Ph}}^{\mathrm{O}}}_{\mathrm{Nh}}$
0.5

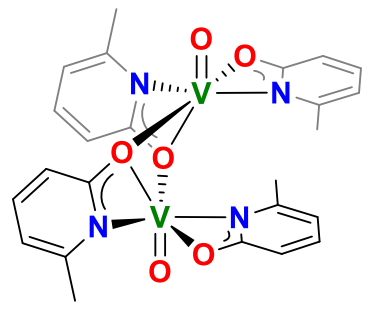

5

Reaction of 1 with Four Equivalents of Benzhydrol: To separate small vials, complex 1 (0.002 g, 0.003 mmol) and benzhydrol $(0.002 \mathrm{~g}, 0.011 \mathrm{mmol})$ were weighed. The alcohol was transferred quantitively to the complex using toluene- $d_{8}$ to give a green coloured solution, which was transferred to a J. Young tube. The total volume of toluene- $d_{8}$ used was $\sim 1 \mathrm{~mL}$. After 75 minutes at room temperature, during which time the ${ }^{1} \mathrm{H}$ NMR spectrum was obtained, the tube was placed in an oil bath set to $140{ }^{\circ} \mathrm{C}$ for 22 hours. The ${ }^{1} \mathrm{H}$ NMR spectrum was obtained once more after the heating was finished, revealing that benzophenone had formed.

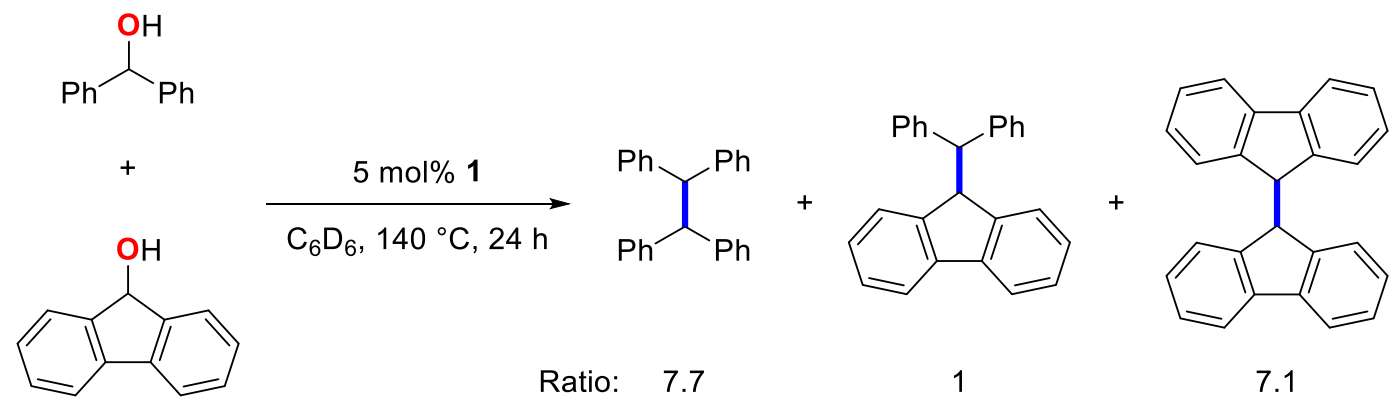

Cross-Over Experiment with Fluorenol: This reaction was carried out in the same way as the catalytic reductive coupling of benzhydrol except that a 1:1 mixture of benzhydrol/fluorenol was used as the substrate ( $0.013 \mathrm{mmol}$ of each alcohol). The ratio of products was estimated by ${ }^{1} \mathrm{H}$ NMR spectroscopy, using the diagnostic benzylic protons for each product. ${ }^{6}$ 


\section{Alcohol Substrate Table}

Table S1. Catalytic Reductive Coupling of Alcohols

\begin{tabular}{|c|c|c|c|c|c|c|}
\hline entry & $\mathrm{R}$ & time $(\mathrm{h})$ & product yield $(\%)^{\mathrm{a}}$ & carbonyl yield (\%) & TON & $\operatorname{TOF}\left(\mathrm{h}^{-1}\right)$ \\
\hline 1 & $\mathrm{Ph}$ & 24 & $>99$ & 88 & 10 & 0.42 \\
\hline 2 & $\mathrm{Me}$ & 48 & $65^{\mathrm{b}}$ & 66 & 6.5 & 0.14 \\
\hline 3 & $\mathrm{H}$ & 48 & 34 & 31 & 3.4 & 0.071 \\
\hline
\end{tabular}

${ }^{\text {a}}$ Yields determined by ${ }^{1} \mathrm{H}$ NMR using 1,3,5-trimethoxybenzene as an internal standard. ${ }^{\mathrm{b}} \mathrm{A}$ 1:1 mixture of meso/racemic diastereomers was observed. 


\section{NMR Spectra}

Figure S1. ${ }^{1} \mathrm{H}$ NMR spectrum of $\mathbf{1}\left(\mathrm{C}_{7} \mathrm{D}_{8}, 300 \mathrm{MHz}, 298 \mathrm{~K}\right)$.

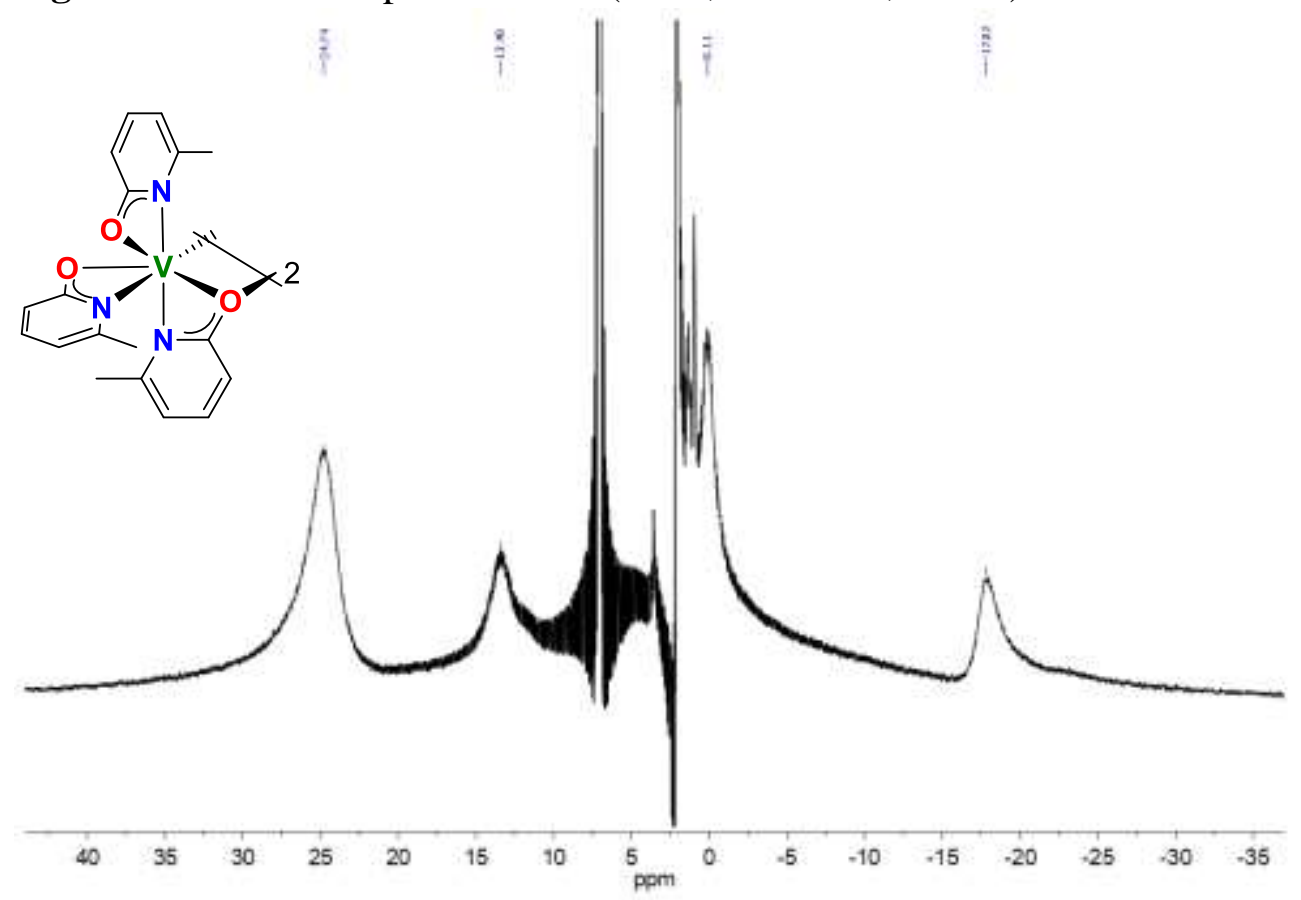

Figure S2. ${ }^{1} \mathrm{H}$ NMR spectrum of $4\left(\mathrm{C}_{7} \mathrm{D}_{8}, 300 \mathrm{MHz}, 298 \mathrm{~K}\right)$.

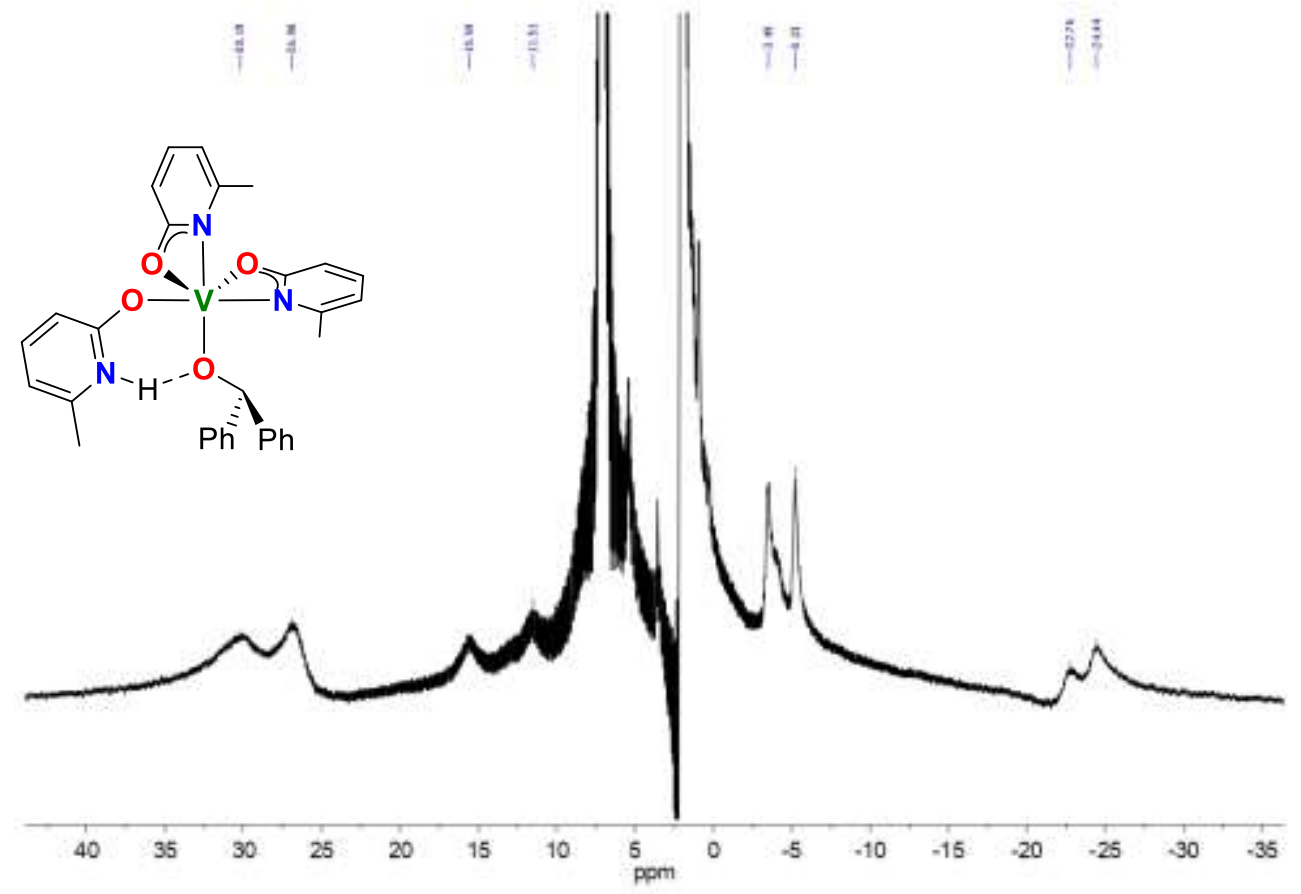


Figure S3. ${ }^{1} \mathrm{H}$ NMR spectrum of $5\left(\mathrm{C}_{7} \mathrm{D}_{8}, 300 \mathrm{MHz}, 298 \mathrm{~K}\right)$.

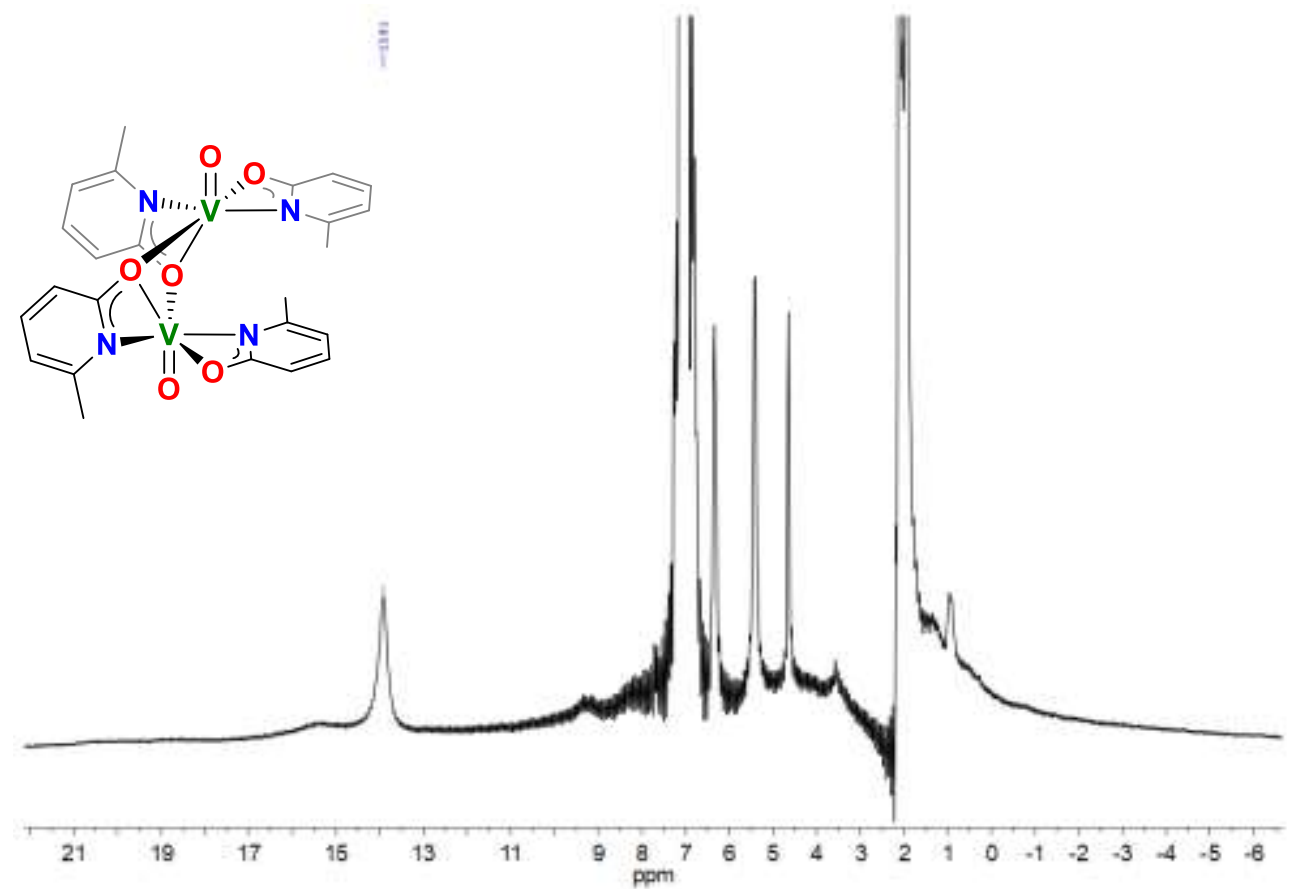

Figure S4. ${ }^{1} \mathrm{H}$ NMR spectrum of catalysis with benzhydrol $\left(\mathrm{C}_{6} \mathrm{D}_{6}, 300 \mathrm{MHz}, 298 \mathrm{~K}\right) .{ }^{5}$

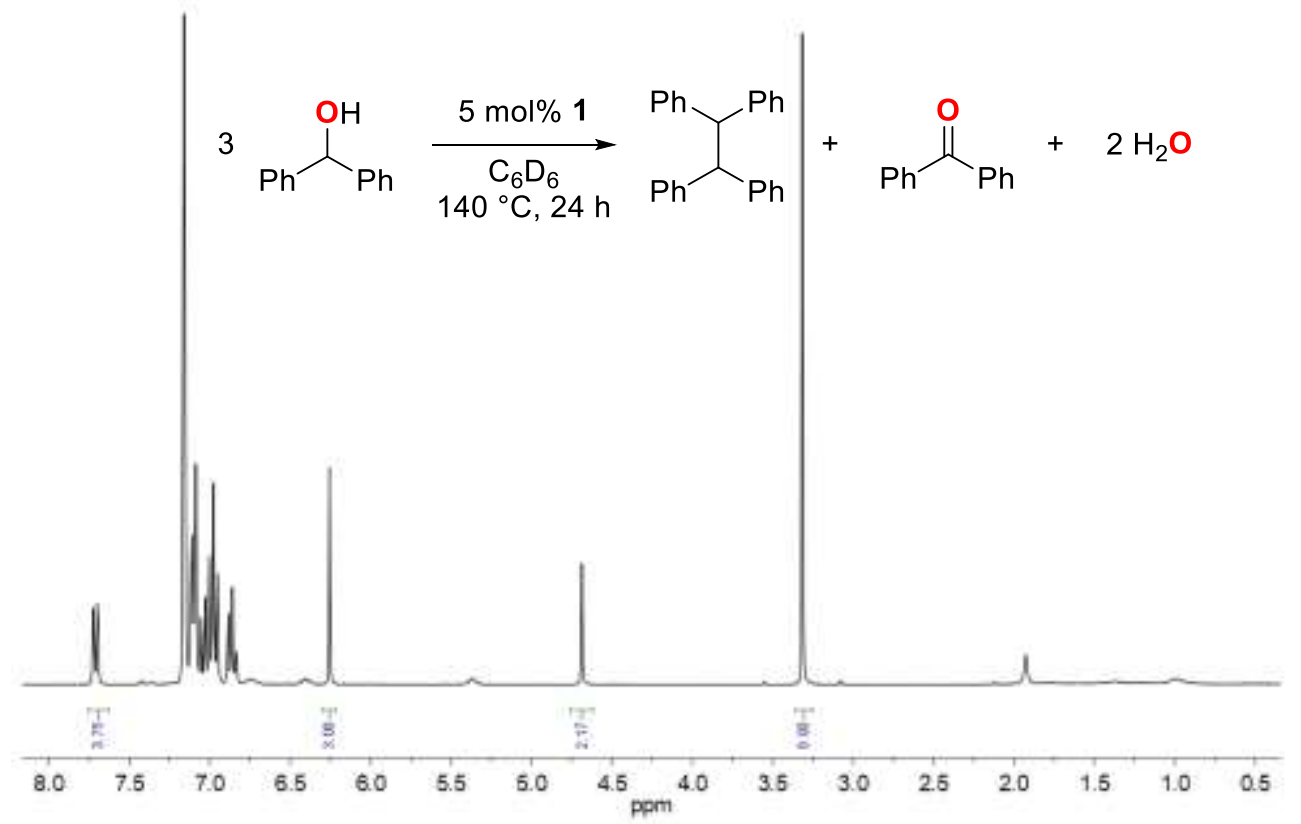


Figure S5. ${ }^{1} \mathrm{H}$ NMR spectrum of catalysis with 1-phenylethanol $\left(\mathrm{C}_{6} \mathrm{D}_{6}, 300 \mathrm{MHz}, 298 \mathrm{~K}\right) .{ }^{5}$

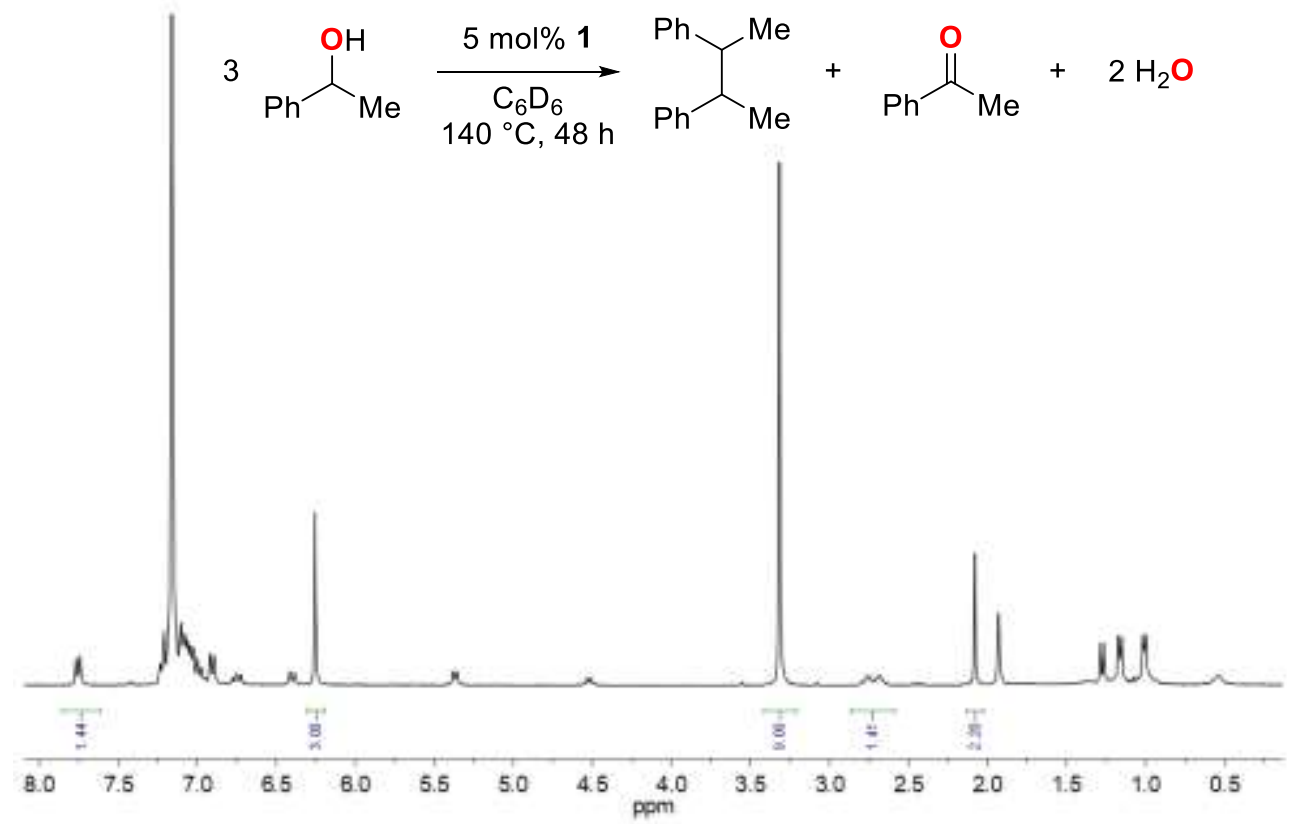

Figure S6. ${ }^{1} \mathrm{H}$ NMR spectrum of catalysis with benzyl alcohol $\left(\mathrm{C}_{6} \mathrm{D}_{6}, 300 \mathrm{MHz}, 298 \mathrm{~K}\right) .{ }^{5}$

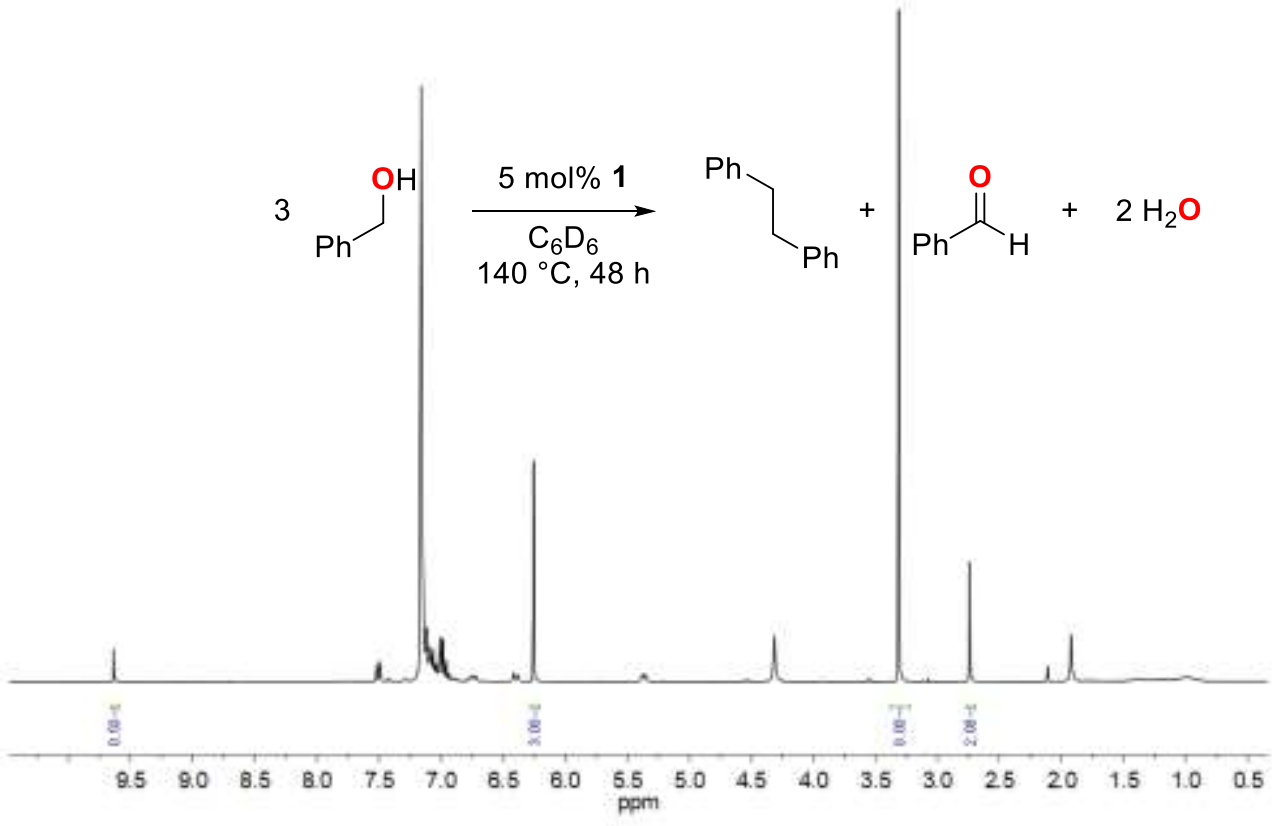


Figure S7. ${ }^{1} \mathrm{H}$ NMR spectrum of the radical ring-opening experiment $\left(\mathrm{C}_{6} \mathrm{D}_{6}, 300 \mathrm{MHz}, 298 \mathrm{~K}\right)$.

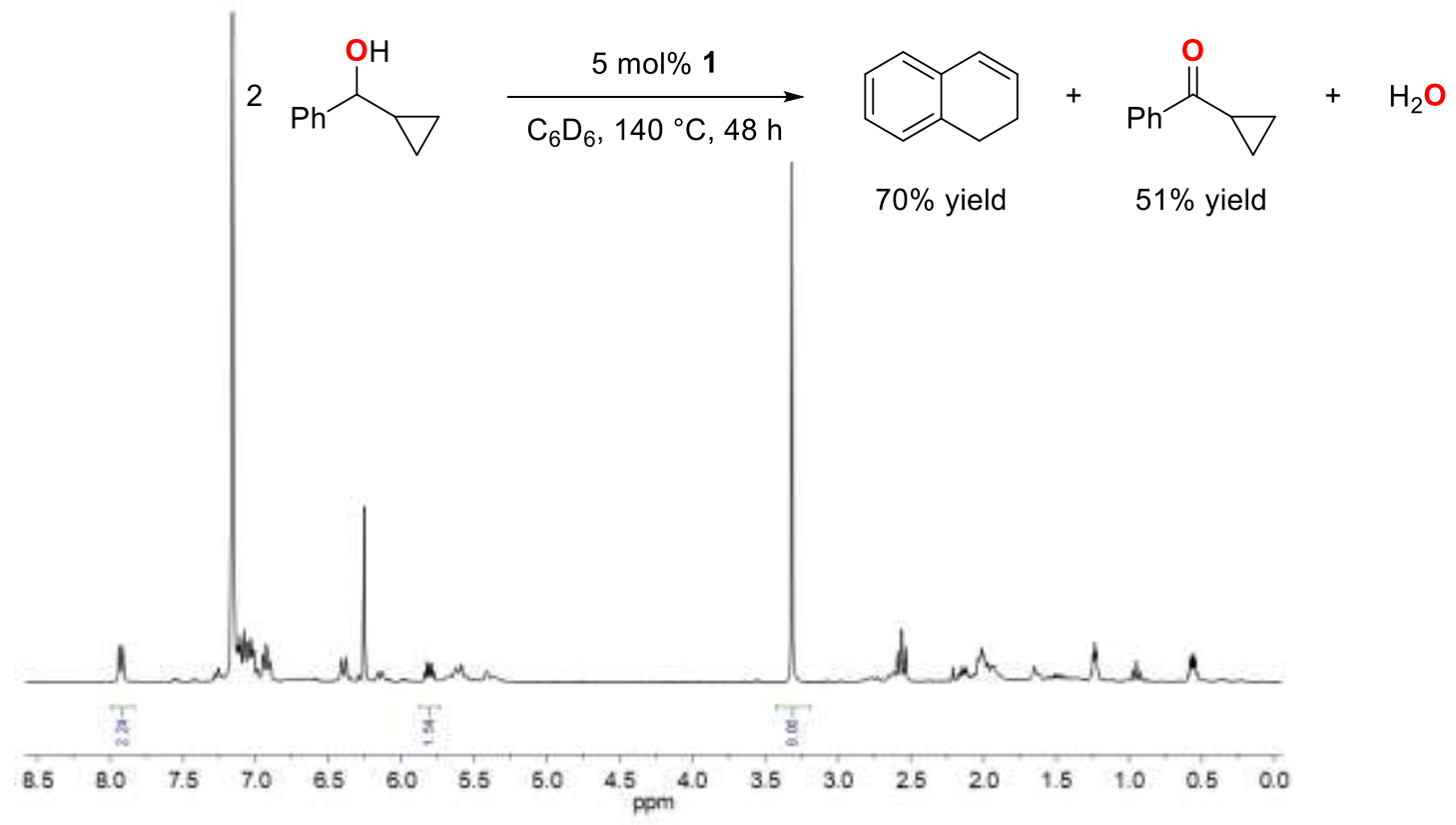

Figure S8. ${ }^{1} \mathrm{H}$ NMR spectrum of the fluorene trapping experiment $\left(\mathrm{C}_{6} \mathrm{D}_{6}, 300 \mathrm{MHz}, 298 \mathrm{~K}\right)$.

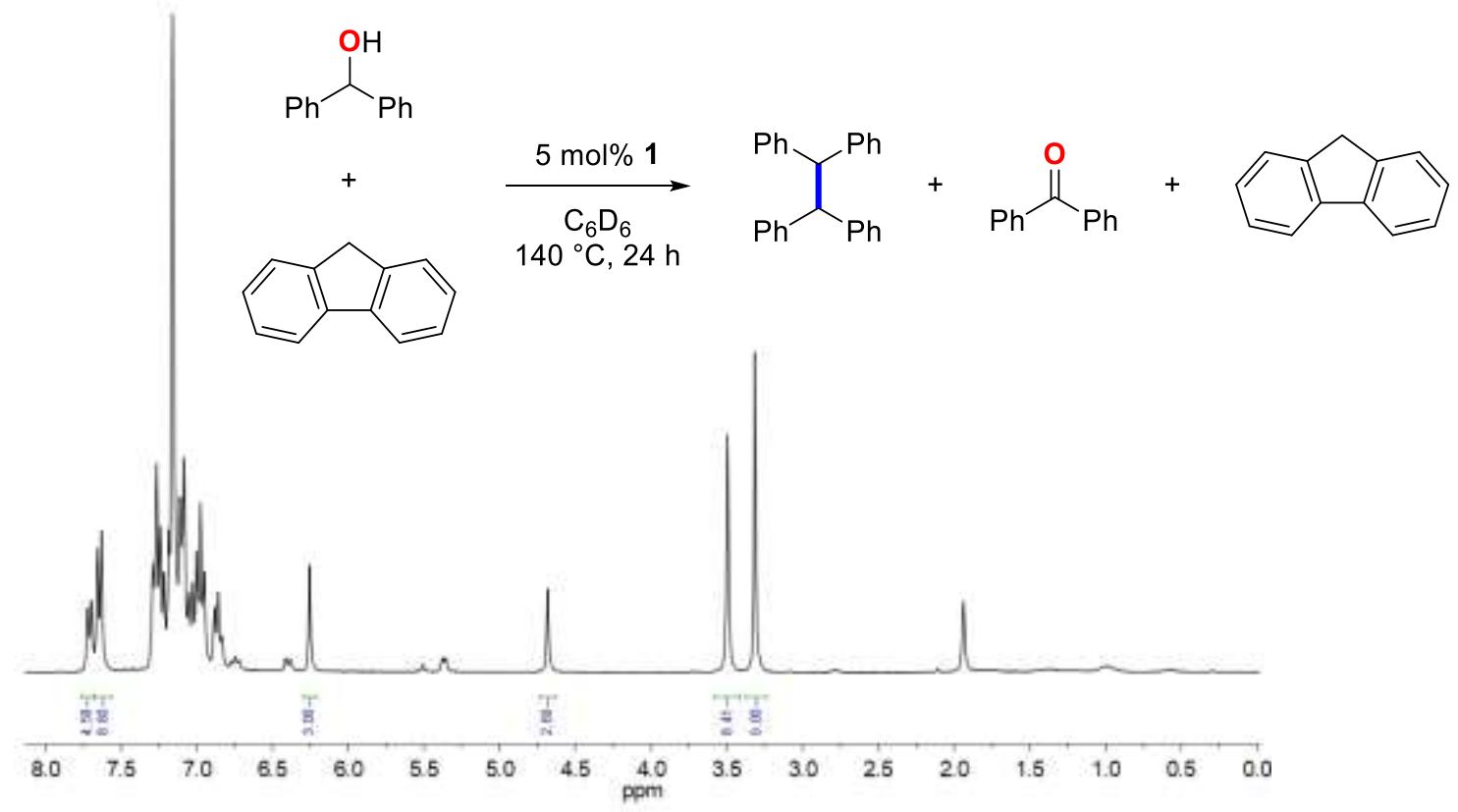


Figure S9. ${ }^{1} \mathrm{H}$ NMR spectrum of the crude 5-catalyzed reaction $\left(\mathrm{C}_{6} \mathrm{D}_{6}, 300 \mathrm{MHz}, 298 \mathrm{~K}\right)$.

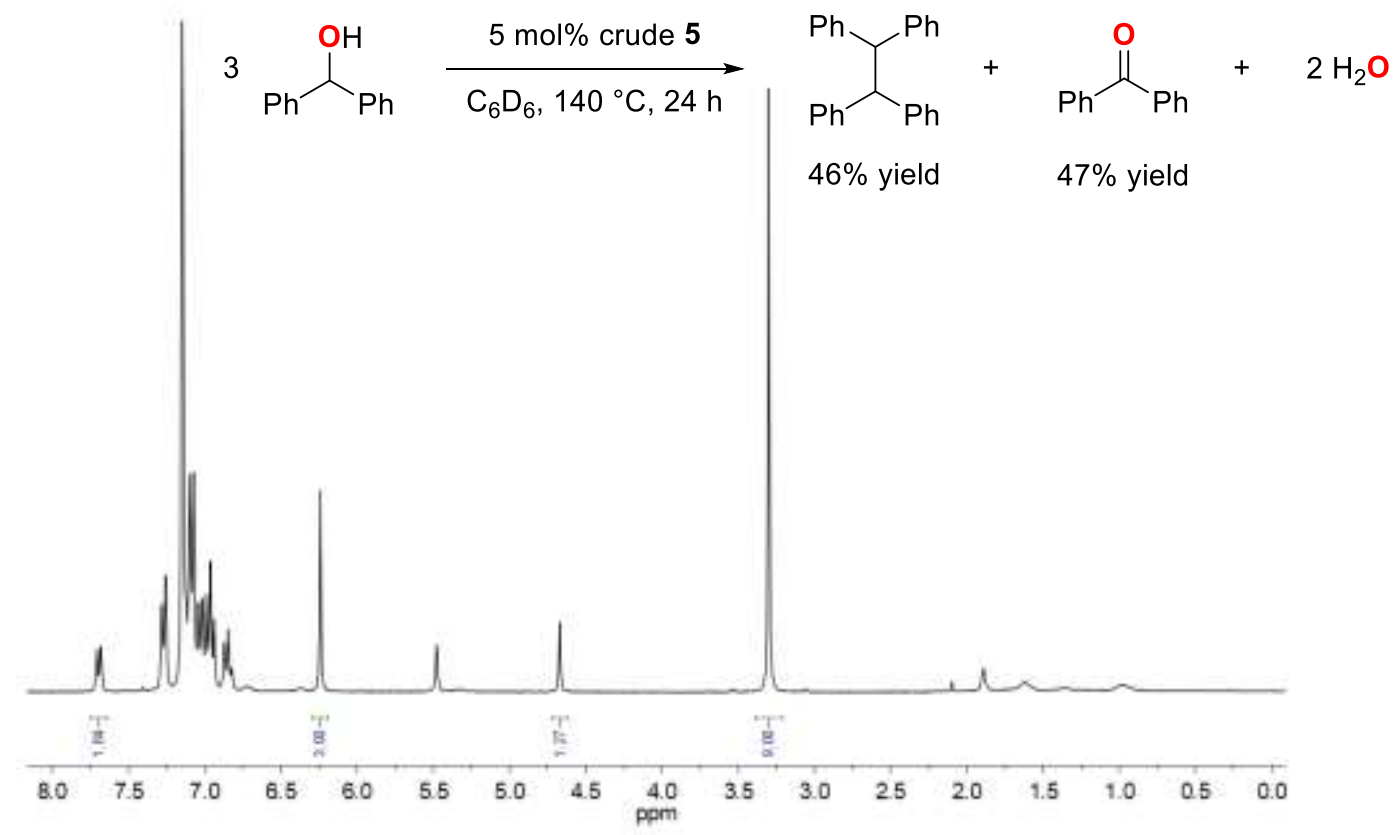

Figure S10. ${ }^{1} \mathrm{H}$ NMR spectrum of the crude 5-catalyzed reaction with added pyridone $3\left(\mathrm{C}_{6} \mathrm{D}_{6}\right.$, $300 \mathrm{MHz}, 298 \mathrm{~K})$.

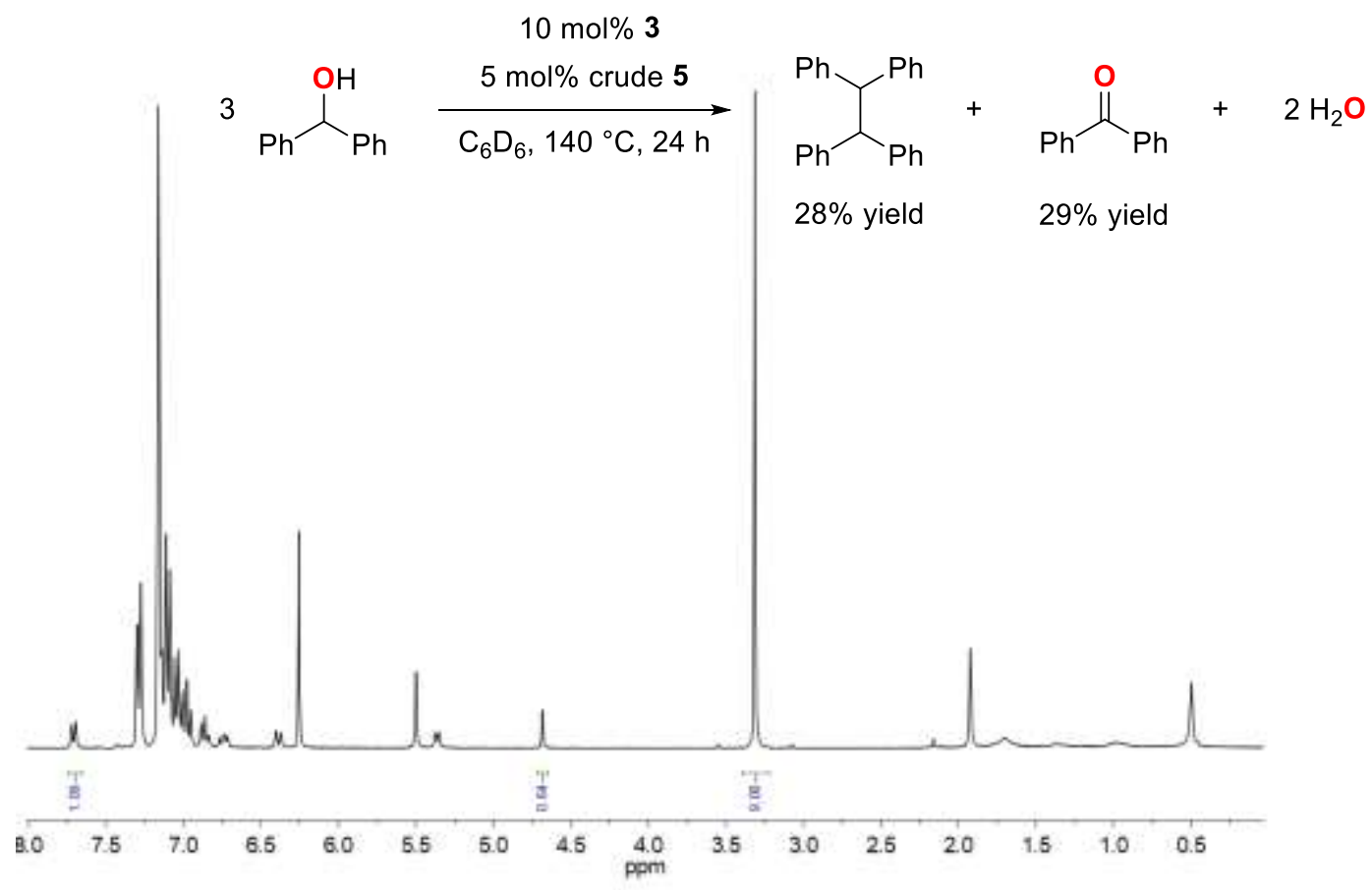


Figure S11. ${ }^{1} \mathrm{H}$ NMR spectrum of 1 and benzhydrol reaction $\left(\mathrm{C}_{7} \mathrm{D}_{8}, 300 \mathrm{MHz}, 298 \mathrm{~K}\right)$.

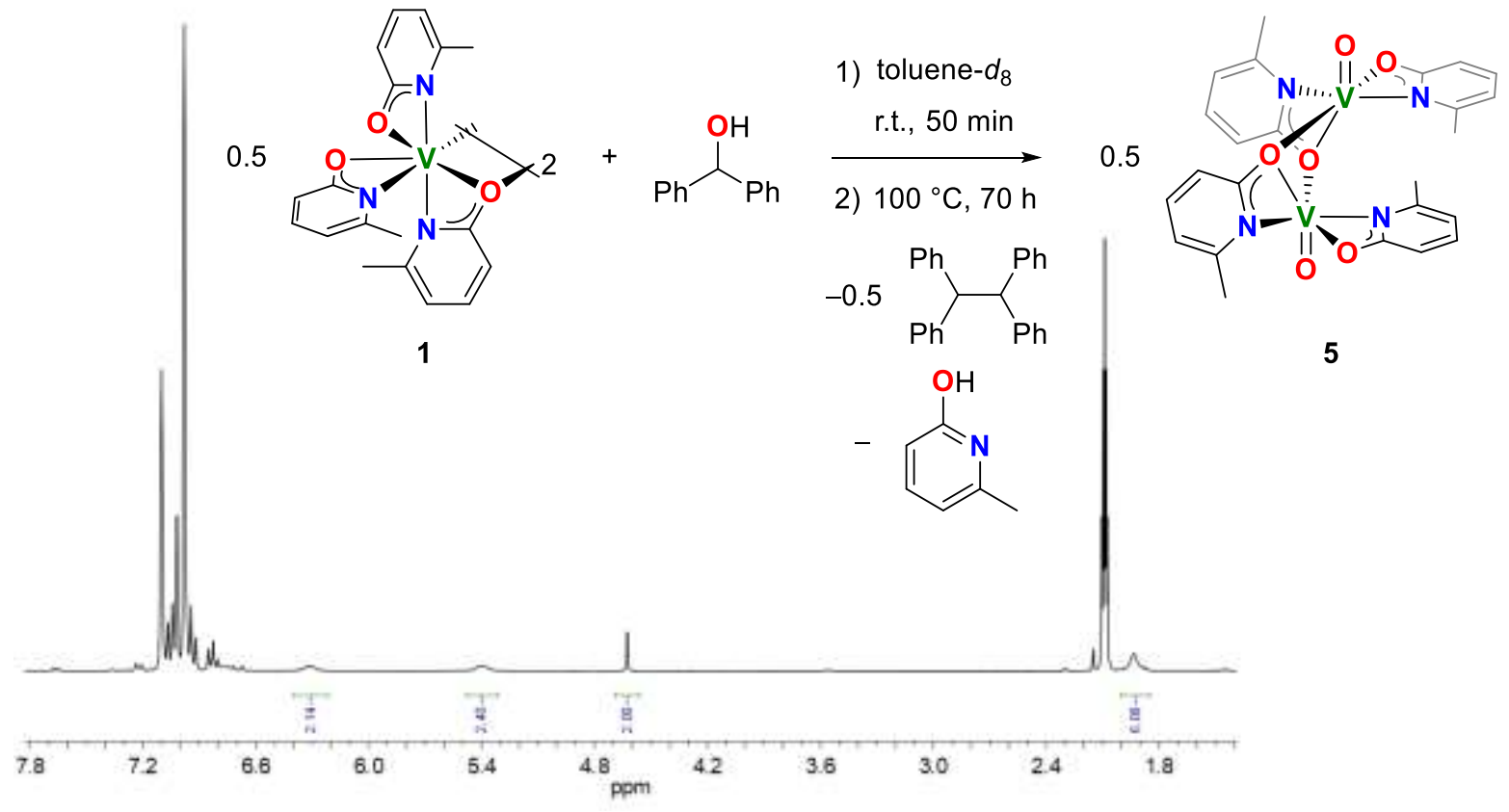

Figure S12. ${ }^{1} \mathrm{H}$ NMR spectrum of the fluorenol cross-over experiment $\left(\mathrm{C}_{6} \mathrm{D}_{6}, 300 \mathrm{MHz}, 298\right.$ K). ${ }^{6}$

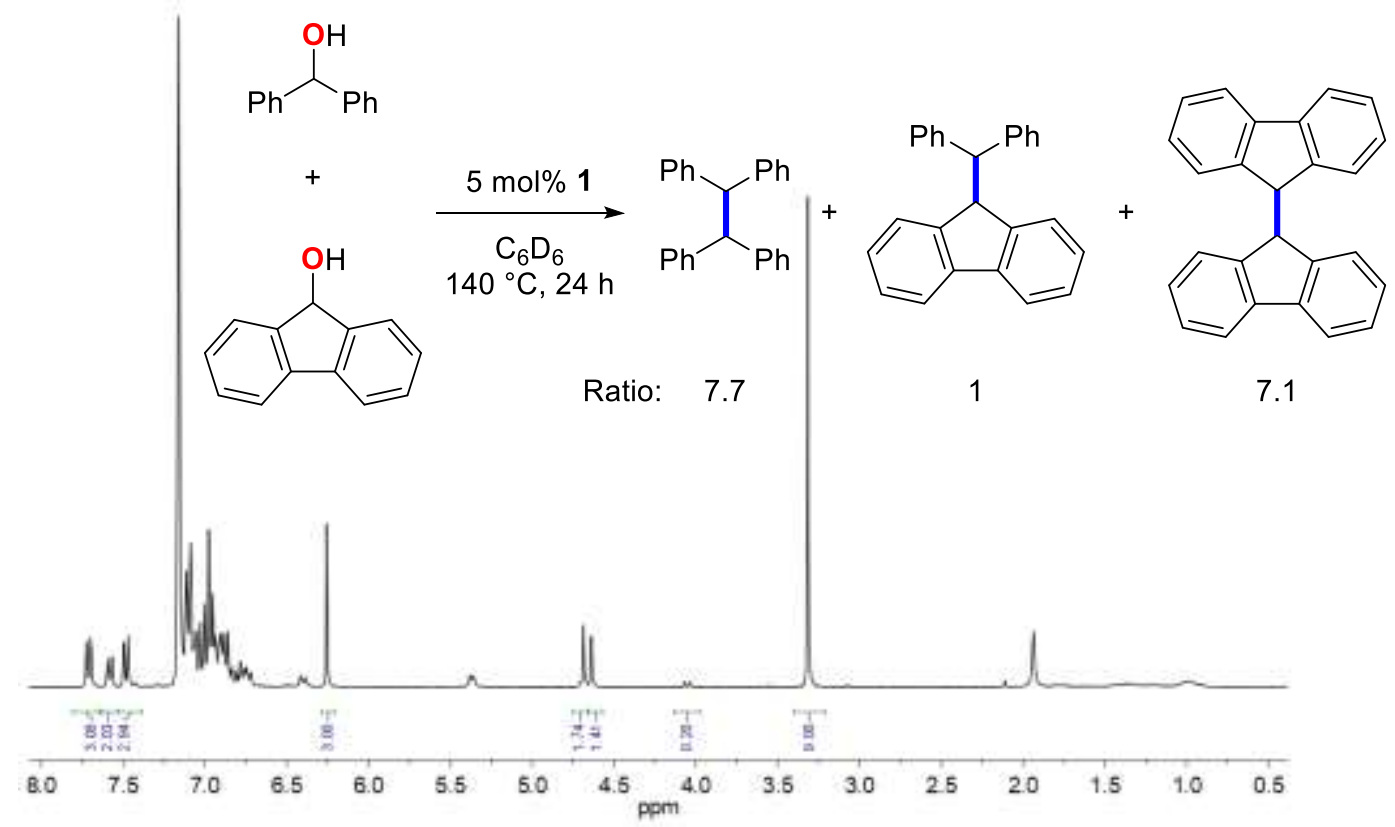


Figure S13. ${ }^{1} \mathrm{H}$ NMR spectrum of 1 and 4 eq. benzhydrol reaction $\left(\mathrm{C}_{7} \mathrm{D}_{8}, 300 \mathrm{MHz}, 298 \mathrm{~K}\right)$.

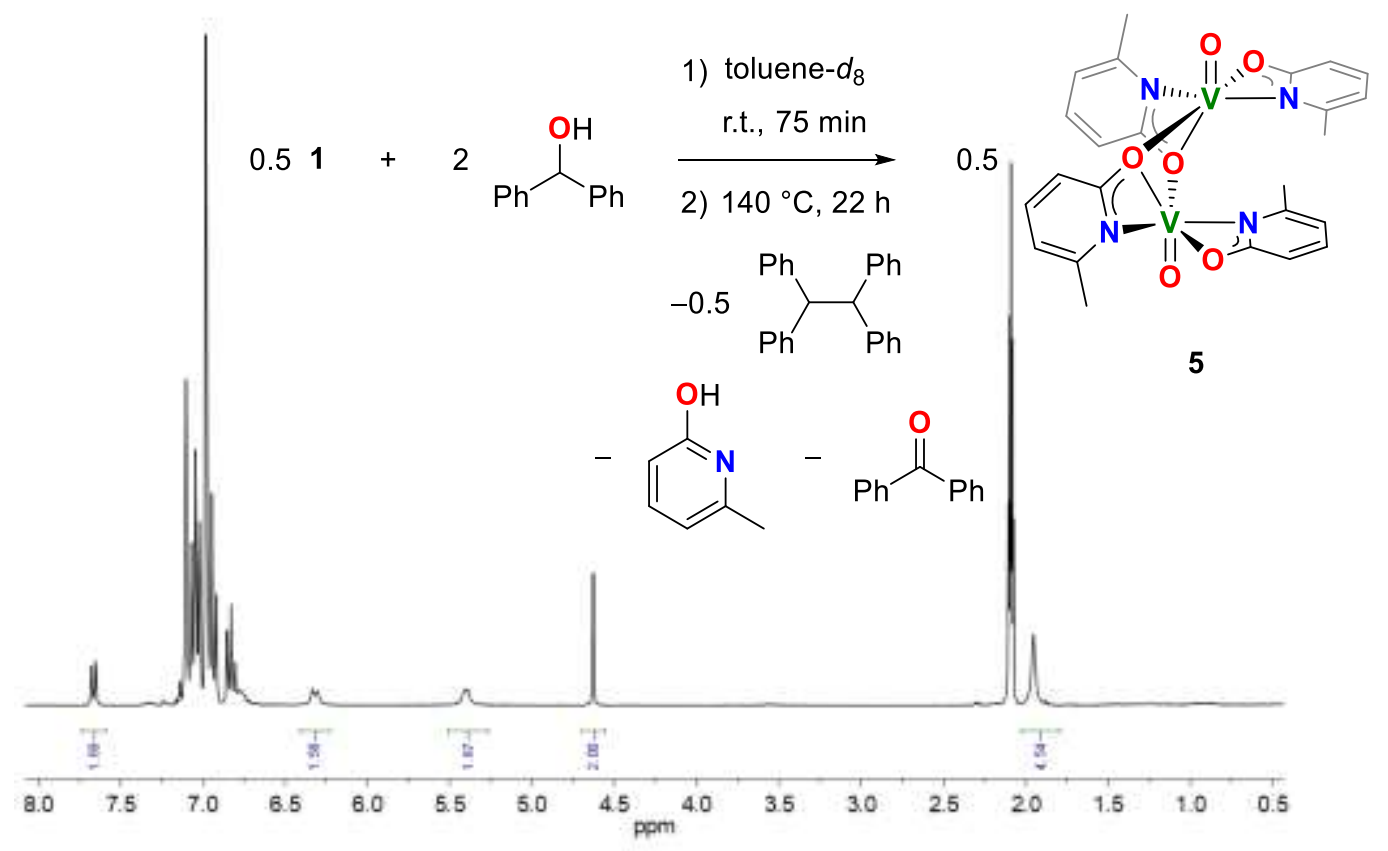

\section{Crystallographic details}

A summary of the crystallographic data for complexes $\mathbf{1 , 4}$, and $\mathbf{5}$ is shown in Table S2. The automatic data collection strategy was determined using COSMO and the cell determination and integration processes were carried out using SAINT. Using Olex $2,{ }^{7}$ the structures were solved with the ShelXT $T^{8}$ structure solution program using Intrinsic Phasing and the structures were refined using the ShelXL ${ }^{9}$ refinement package using the Least Squares method. The unit cell determined for the colourless crystals obtained during the synthesis of 5 matched that of 1,1,2,2tetraphenylethane from a previous report. ${ }^{10}$

CCDC 1939764, 1939765, and 1939766 contain the supplementary crystallographic data for this paper. These data are provided free of charge by The Cambridge Crystallographic Data Centre. 


\section{Crystallographic tables:}

Table S2. List of crystallographic parameters for compounds 1, 4, and $\mathbf{5 .}$

Compound

Empirical formula

Formula weight

Temperature/K

Crystal system

Space group

$\mathrm{a} / \AA$

$\mathrm{b} / \AA$

c/Å

$\alpha{ }^{\circ}$

$\beta /{ }^{\circ}$

$\gamma /{ }^{\circ}$

Volume/ $\AA^{3}$

$\mathrm{Z}$

$\rho_{\text {calc }} \mathrm{g} / \mathrm{cm}^{3}$

$\mu / \mathrm{mm}^{-1}$

$\mathrm{F}(000)$

Crystal size $/ \mathrm{mm}^{3}$

Radiation

$2 \Theta$ range for data collection/ ${ }^{\circ}$

Index ranges

Reflections collected

Independent reflections

Data/restraints/parameters

Goodness-of-fit on $\mathrm{F}^{2}$

Final $\mathrm{R}$ indexes $[\mathrm{I}>=2 \sigma(\mathrm{I})]$

Final $\mathrm{R}$ indexes [all data]

Largest diff. peak/hole / e $\AA^{-3}$

Flack parameter
1

$\mathrm{C}_{18} \mathrm{H}_{18} \mathrm{~N}_{3} \mathrm{O}_{3} \mathrm{~V}$

375.29

100

monoclinic

Pn

12.3071(6)

$10.3510(6)$

$13.5916(7)$

90

91.199(3)

90

1731.07(16)

4

1.440

0.595

776.0

$0.14 \times 0.08 \times 0.05$

$\operatorname{MoK} \alpha(\lambda=0.71073)$

3.934 to 52.69

$-13 \leq \mathrm{h} \leq 15,0 \leq \mathrm{k} \leq 12,-16 \leq 1 \leq$ 16

6177

$6177\left[\mathrm{R}_{\mathrm{int}}=0.0505, \mathrm{R}_{\text {sigma }}=\right.$ $0.0510]$

$6177 / 2 / 457$

1.065

$\mathrm{R}_{1}=0.0396, \mathrm{wR}_{2}=0.0862$

$\mathrm{R}_{1}=0.0507, \mathrm{wR}_{2}=0.0912$

$0.33 /-0.35$

$-0.036(15)$
4

$\mathrm{C}_{31} \mathrm{H}_{30} \mathrm{~N}_{3} \mathrm{O}_{4} \mathrm{~V}$

559.52

90

triclinic

$\mathrm{P}-1$

9.0669(16)

$10.4121(19)$

$14.970(3)$

96.110(5)

98.347(4)

101.792(5)

1355.2(4)

2

1.371

0.408

584.0

$0.17 \times 0.1 \times 0.04$

$\operatorname{MoK} \alpha(\lambda=0.71073)$

2.778 to 61.346

$-12 \leq \mathrm{h} \leq 12,-14 \leq \mathrm{k} \leq 14,-21 \leq$

$1 \leq 21$

48010

$8308\left[\mathrm{R}_{\text {int }}=0.0642, \mathrm{R}_{\text {sigma }}=\right.$ $0.0430]$ $8308 / 0 / 355$

1.076

$\mathrm{R}_{1}=0.0520, \mathrm{wR}_{2}=0.1385$

$\mathrm{R}_{1}=0.0660, \mathrm{wR}_{2}=0.1485$

$1.41 /-0.93$ 
Compound

Empirical formula

Formula weight

Temperature/K

Crystal system

Space group

$\mathrm{a} / \AA$

$\mathrm{b} / \AA$

$\mathrm{c} / \AA$

$\alpha /{ }^{\circ}$

$\beta /{ }^{\circ}$

$\gamma /{ }^{\circ}$

Volume $/ \AA^{3}$

$\mathrm{Z}$

$\rho_{\text {calc }} \mathrm{g} / \mathrm{cm}^{3}$

$\mu / \mathrm{mm}^{-1}$

$\mathrm{F}(000)$

Crystal size $/ \mathrm{mm}^{3}$

Radiation

$2 \Theta$ range for data collection/ ${ }^{\circ}$

Index ranges

Reflections collected

Independent reflections

Data/restraints/parameters

Goodness-of-fit on $\mathrm{F}^{2}$

Final R indexes $[\mathrm{I}>=2 \sigma(\mathrm{I})]$

Final $R$ indexes [all data]

Largest diff. peak/hole / e $\AA^{-3}$

Flack parameter
5

$\mathrm{C}_{24} \mathrm{H}_{24} \mathrm{~N}_{4} \mathrm{O}_{6} \mathrm{~V}_{2}$

566.35

90

monoclinic

Pn

7.9562(6)

$9.7274(7)$

16.0900(11)

90

95.631(2)

90

$1239.25(15)$

2

1.518

0.801

580.0

$0.25 \times 0.24 \times 0.14$

$\operatorname{MoK} \alpha(\lambda=0.71073)$

4.188 to 61.154

$-11 \leq \mathrm{h} \leq 11,-13 \leq \mathrm{k} \leq 13,-23$

$\leq 1 \leq 23$

37824

$7323\left[\mathrm{R}_{\text {int }}=0.0281, \mathrm{R}_{\text {sigma }}=\right.$ $0.0256]$

$7323 / 2 / 330$

1.049

$\mathrm{R}_{1}=0.0235, \mathrm{wR}_{2}=0.0576$

$\mathrm{R}_{1}=0.0252, \mathrm{wR}_{2}=0.0584$

$0.38 /-0.20$

$0.147(13)$ 
Figure S12. ORTEP representation of complex 1 with ellipsoids shown at 50\% probability and hydrogen atoms omitted for clarity. Selected bond lengths $(\AA)$ : V1-N2, 2.167(4); V2-N3, 2.170(4); V2-N4, 2.101(4); V1-O2, 2.053(3); V2-O3, 2.184(3); V1-O3, 2.078(3); V2-O4, 2.060(3). Selected bond angles (deg): O2-V1-N2, 63.18(15); V1-O3-V2, 102.67(13).

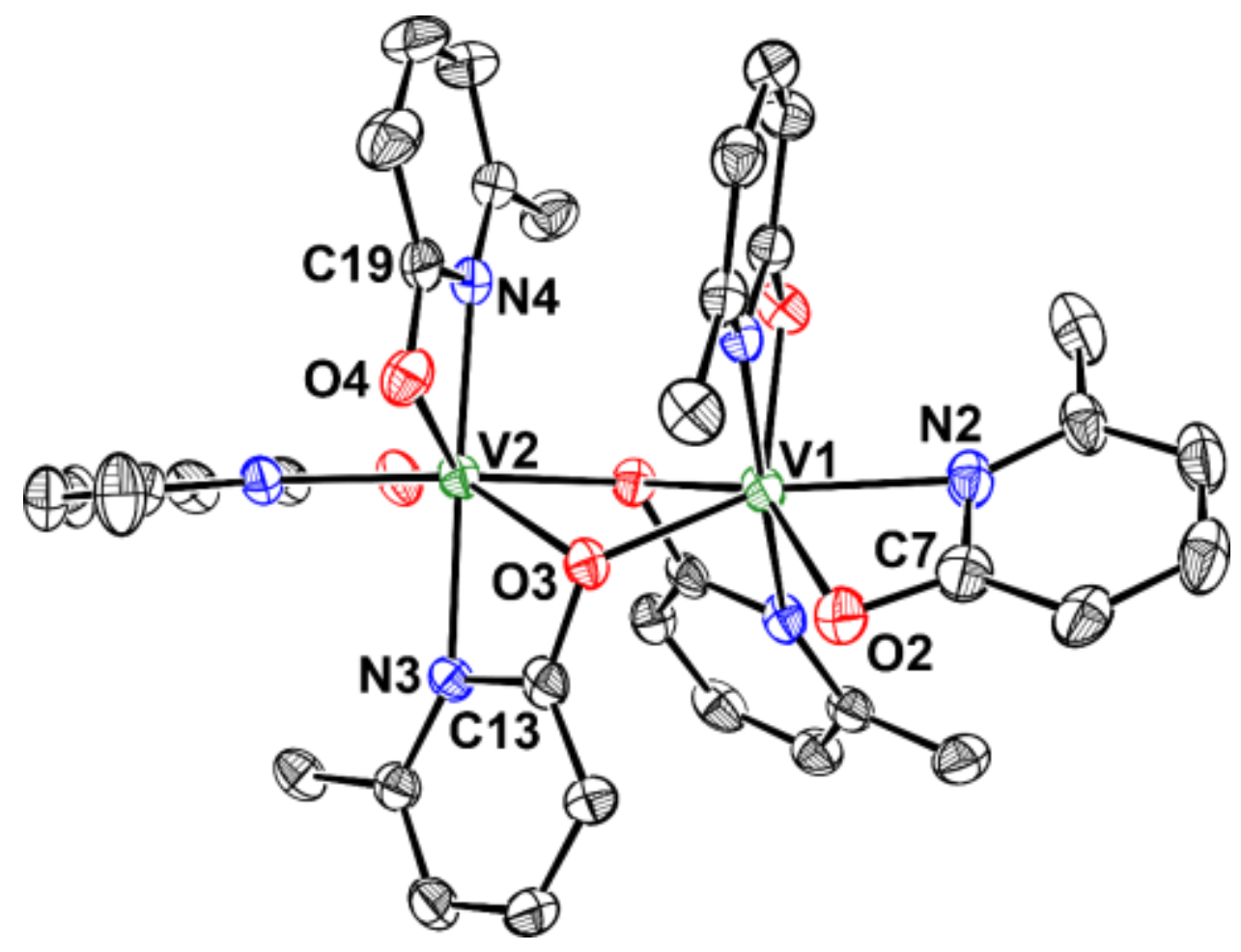


Figure S13. ORTEP representation of complex 4 with ellipsoids shown at 50\% probability and hydrogen atoms omitted for clarity. Selected bond lengths $(\AA)$ : V1-N1, 2.1482(15); V1-N2, 2.1960(16); V1-O1, 1.9922(14); V1-O2, 2.0081(13); V1-O3, 2.0446(13); V1-O4, 1.8888(14); $\mathrm{O} 4-\mathrm{H} 3,1.914$ (calc). Selected bond angles (deg): O1-V1-N1, 64.55(6); C13-O3-V1, 136.39(12); V1-O4-C19, 128.34(11).

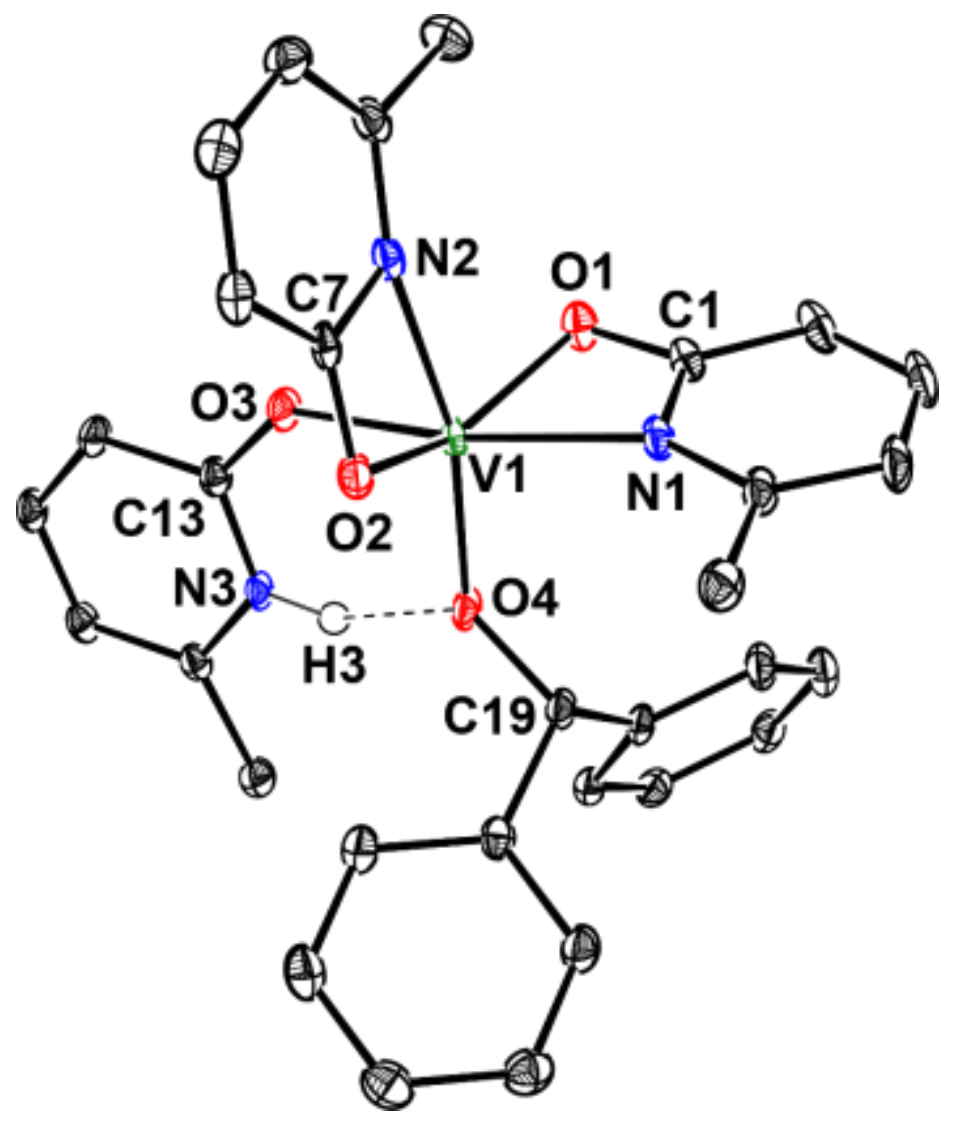


Figure S14. ORTEP representation of complex 5 with ellipsoids shown at 50\% probability and hydrogen atoms omitted for clarity. Selected bond lengths $(\AA)$ : V1-N1, 2.0840(17); V1-N2, 2.1096(16); V2-N3, 2.0829(17); V2-N4, 2.0984(17); V1-O1, 1.5931(14); V1-O2, 2.0031(15); V1-O3, 2.4520(14); V2-O3, 2.0039(15); V2-O4, 1.5954(15); V2-O5, 1.9989(16); V2-O6, 2.4454(14). Selected bond angles (deg): O2-V1-N1, 65.50(7); V1-O6-V2, 107.01(6); $\mathrm{O} 1-\mathrm{V} 1-\mathrm{O} 3,157.02(6)$.

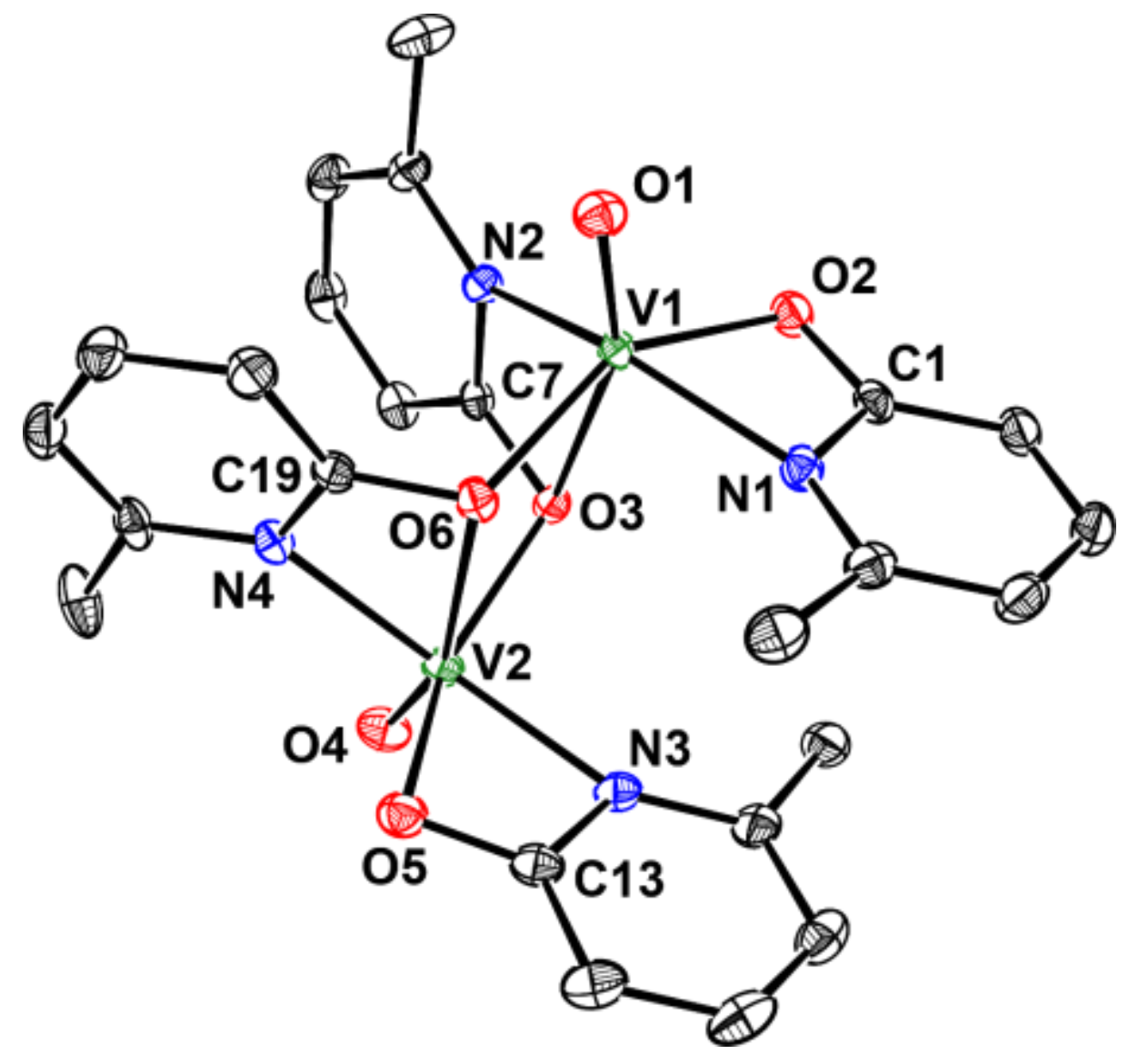




\section{References}

(1) Evans, D. F. 400. The Determination of the Paramagnetic Susceptibility of Substances in Solution by Nuclear Magnetic Resonance. J. Chem. Soc. 1959, 0, 2003.

(2) Sur, S. K. Measurement of Magnetic Susceptibility and Magnetic Moment of Paramagnetic Molecules in Solution by High-Field Fourier Transform NMR Spectroscopy. J. Magn. Reson. 1989, 82, 169.

(3) Grant, D. H. Paramagnetic Susceptibility by NMR: The "Solvent Correction" Reexamined. J. Chem. Educ. 1995, 72, 39.

(4) Vivanco, M.; Ruiz, J.; Floriani, C.; Chiesi-Villa, A.; Rizzoli, C. Chemistry of the Vanadium-Carbon .Sigma. Bond. 1. Insertion of Carbon Monoxide, Isocyanides, Carbon Dioxide, and Heterocumulenes into the V-C Bond of Tris(Mesityl)Vanadium(III). Organometallics 1993, 12, 1794.

(5) Steffensmeier, E.; Nicholas, K. M. Oxidation-Reductive Coupling of Alcohols Catalyzed by OxoVanadium Complexes. Chem. Commun. 2018, 54, 790.

(6) Kasner, G. R.; Boucher-Jacobs, C.; Michael McClain, J.; Nicholas, K. M. Oxo-Rhenium Catalyzed Reductive Coupling and Deoxygenation of Alcohols. Chem. Commun. 2016, 52, 7257.

(7) Dolomanov, O. V.; Bourhis, L. J.; Gildea, R. J.; Howard, J. A. K.; Puschmann, H. OLEX2: A Complete Structure Solution, Refinement and Analysis Program. J. Appl. Cryst. 2009, 42, 339.

(8) Sheldrick, G. M. SHELXT - Integrated Space-Group and Crystal-Structure Determination. Acta Cryst. Sect. A 2015, 71, 3.

(9) Sheldrick, G. M. Crystal Structure Refinement with SHELXL. Acta Cryst. Sect. C 2015, 71, 3.

(10) Dowling, G.; Kavanagh, P. V.; Talbot, B.; O’Brien, J.; Hessman, G.; McLaughlin, G.; Twamley, B.; Brandt, S. D. Outsmarted by Nootropics? An Investigation into the Thermal Degradation of Modafinil, Modafinic Acid, Adrafinil, CRL-40,940 and CRL-40,941 in the GC Injector: Formation of 1,1,2,2-Tetraphenylethane and Its Tetra Fluoro Analog. Drug Test. Anal. 2017, 9, 518. 